\title{
VÝSLEDKY DENDROCHRONOLOGICKÉHO VÝSKUMU OBYTNEJ VEŽE TRENČIANSKEHO HRADU
}

\author{
PETER BARTA - MARTIN BÓNA
}

\begin{abstract}
Abstrakt: Príspevok približuje výsledky dendrochronologického výskumu piatich stavebných driev obytnej veže, ktorá patrí $k$ najstarším zachovaným profánnym objektom komitátneho Trenčianskeho hradu. Vzorkované drevá tvoria zvyšky stropného prievlaku a trámov ochodze staršieho románskeho jadra veže. Datovanie doby výrubu pre štyri z piatich vzorkovaných drevených prvkov prináša nové argumenty pre datovanie výstavby veže a dopĺn̆a doterajšie predstavy o časovom zaradení najstaršich architektúr hradu.
\end{abstract}

Kl'účové slová: dendrochronologický výskum - architektonicko-historický výskum - Trenčiansky hrad obytná veža.

\section{Results of dendrochronological research of the residential tower of Trenčín Castle}

Abstract: This article introduces dendrochronological research of timbers from the residential tower, one of the oldest preserved profane buildings of Trenčin Castle. In its earlier Romanesque stone masonry, remains of five oak beams survived: a central ceiling beam, three supports of parapet walk, and a beam of unknown function. Four of them were successfully dated and produced first chronometric evidence for the construction of the tower. Our research presents the most recent contribution to the historic-architectural and archaeological discussions on chronology of the earliest architectures of this county castle.

Key words: dendrochronological research - architectural-historical research - Trenčin Castle - residential tower.

Dendrochronologický výskum stavebných driev obytnej veže Trenčianskeho hradu sa uskutočnil v dvoch etapách v rokoch 2010 a 2018 autormi príspevku, ktorí ho iniciovali v záujme o exaktnejšie datovanie objektu. ${ }^{1}$ Dovtedajšie úvahy o možnom vzniku stavby sa opierali o architektonicko-historické hodnotenia a o archívne pramene, ktoré pripúštali vznik veže v rozmedzí 11. až 12. storočia.

\section{Situácia a stručný opis stavby s pozíciou vzorkovaných driev}

Ucelene zachovaná hranolová sedempodlažná veža dominuje na vrchole vápencového brala v centrálnej časti horného hradu (obr. 1). Jej dnešný vzhl'ad je výsledkom pamiatkovej obnovy v 70. rokoch 20. storočia, ktorou sa prinavrátil a čiastočne zrekonštruoval jej stredoveký vzhlad s mal’ovaným kvádrovaním fasád a doplnili chýbajúce stropné a klenbové konštrukcie (bližšie Fiala 1988, 73).

Vstup do sedempodlažnej stavby je cez hrotitý portál na 2. podlaží, ústiaci do interiéru susedného paláca. Z klenutého 2. podlažia je cez otvor v podlahe prístupné tmavé klenuté prízemie. Do vyšších štyroch podlaží, striedavo prekrytých klenbami a trámovými stropmi, sa vstupuje cez hrotité portály. Tie sú napojené na schodisko v hrúbke múru, presvetlené štrbinovými okienkami s rôznorodo stvárnenými kamennými osteniami. Miestnosti presvetl'ujú štrbinové okná a hlavnú obytnú miestnost's rebrovou klenbou na 5. podlaží väčšie združené okná s výklenkovými kamennými sedadlami. Z najvyššieho 7. podlažia prístupného točitým schodiskom v hrúbke múru sa vystupuje aj na obnovenú vrcholovú ochodzu, prekrytú ihlanovou strechou veže.

Vzorkované drevené prvky sa nachádzajú v južnej a severnej stene 3. podlažia, kde zostali odprezentované po pamiatkovej úprave $\mathrm{v} 70$. rokoch 20 . storočia ako autentické prvky románskeho jadra veže.

1 Na tomto mieste by sme radi vyjadrili pod’akovanie vedeniu Trenčianskeho múzea, ktoré nám v rokoch 2010 a 2018 ochotne sprístupnilo priestory veže pre účely vzorkovania stavebných driev. 


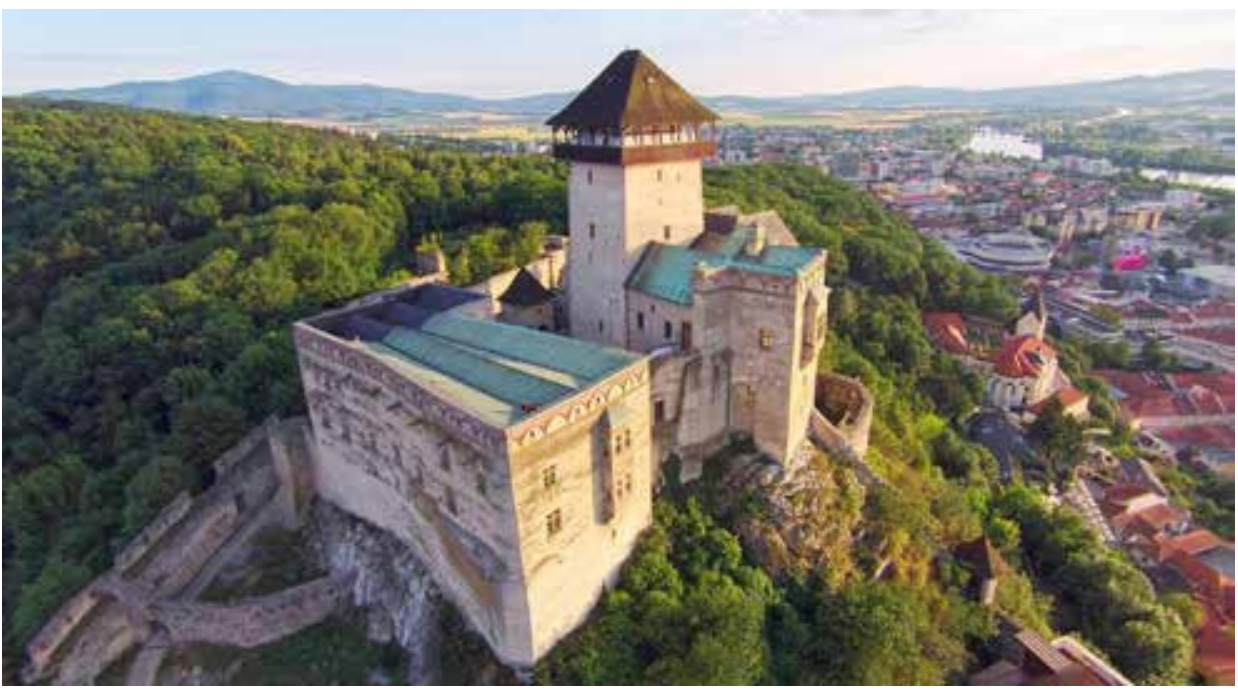

Obr. 1. Trenčiansky hrad. Letecký pohl’ad na horný hrad s obytnou vežou. Foto M. Haulík, 2014. Abb. 1. Burg Trenčín. Luftaufnahme von der oberen Burg mit Wohnturm. Foto M. Haulík, 2014.

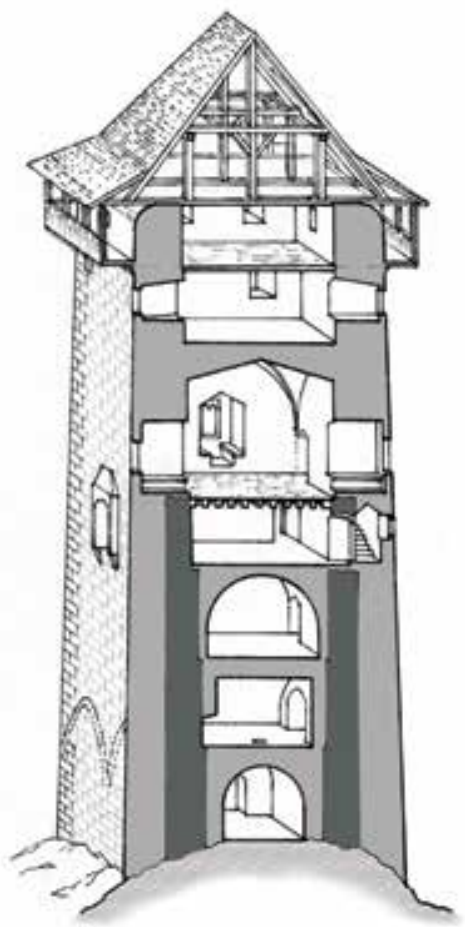

Obr. 2. Trenčiansky hrad. Rezoaxonometria obytnej veže s vyznačením románskeho jadra. Kresba M. Bóna.

Abb. 2. Burg Trenčín. Axonometrische Darstellung des Wohnturms mit Kennzeichnung des romanischen Kerns. Zeichnung M. Bóna.

\section{Doterajšie zistenia o vývoji veže na základe pamiatkových výskumov}

Najstaršie pamiatkové prieskumy hradu realizované na sklonku 19. až začiatku 20. storočia K. Werdenstetterom, J. Könyökim a K. Luxom mali zväčša dokumentačný ciel' a nevenovali pôvodu obytnej veže väčšiu pozornost. ${ }^{2}$ Odborný architektonicko-historický prieskum hradnej zrúcaniny uskutočnila až v polovici 20. storočia D. Menclová, ktorá vznik šest'podlažnej obytnej veže predpokladala v 60. rokoch 13. storočia, opierajúc svoju argumentáciu aj o dispozičnú podobnost's vežou Šarišského hradu (Menclová 1956, 12-13). Neskôr pripustila, že odlišnost' materiálu obvodového muriva s kamenným vnútrom a tehlovým pláštom môže indikovat' existenciu staršieho jadra veže (1973, 410-411). V roku 1976 uskutočnil A. Fiala híbkový výskum objektu a dospel k záverom, že v hmote tehlovej ranogotickej stavby sa ucelene zachovalo kamenné murivo staršej štvorpodlažnej veže s vonkajšími rozmermi $8 \times 8 \mathrm{~m}$ (obr. 2 a 3 ). $\mathrm{V}$ rámci tejto identifikoval zvyšky vstupného portálu na 2. podlaží a zvyšky kozubov na

2 Dokumentačné správy a grafické materiály sú archivované vo Forster Gyula Nemzeti Örökségvédelmi és Vagyongazdálkodási Központ Budapest. 


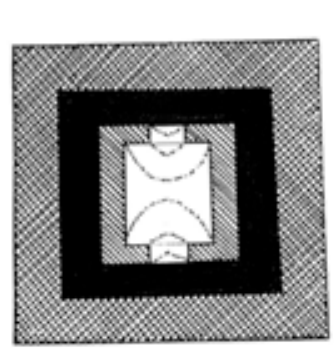

1. NP

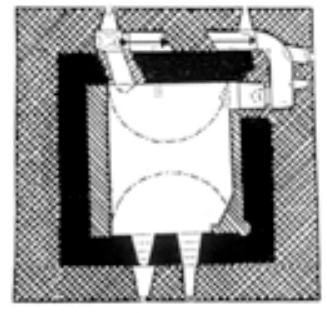

3. NP

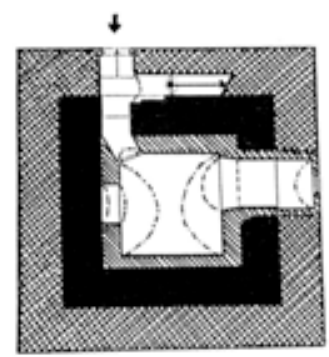

2. NP

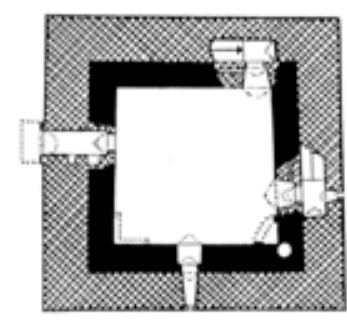

4. NP
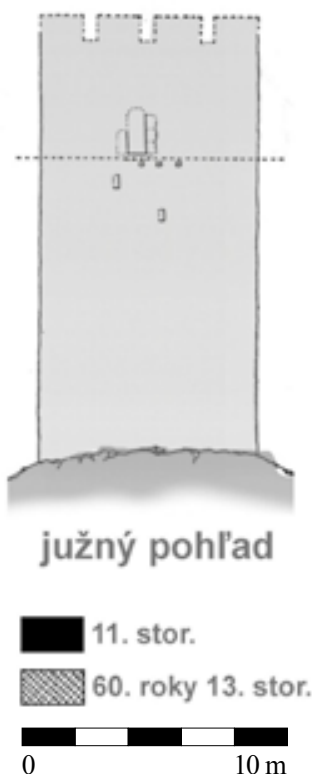

Obr. 3. Trenčiansky hrad. Analytické pôdorysy a rekonštruovaný pohl’ad na románsku vežu. Podl’a A. Fiala $1976 ; 1977$. Abb. 3. Burg Trenčín. Analytischer Grundriss und rekonstruierte Ansicht des romanischen Turms. Nach A. Fiala 1976; 1977.

dvoch horných obytných podlažiach. Kozub na 4. podlaží si zachoval aj kamenné štvrt'kruhové konzolky a $\mathrm{v}$ jeho susedstve sa odkryl spodok portálu na vonkajšiu vysunutú drevenú ochodzu, doloženú lôžkami konzolových trámov. Jednotlivé podlažia boli oddelené trámovými stropmi, pričom zo stropu pôvodného 3. nadzemného podlažia sa zachoval aj zvyšok stredového prievlaku.

Pri hladaní opory pre datovanie najstaršej časti veže sa A. Fiala opieral o prítomnost' susednej archeologicky odkrytej sakrálnej stavby kruhového pôdorysu z 11. storočia, ako aj o najstaršie písomné zmienky o Trenčianskom hrade z rokov 1090 až 1113. Na základe týchto usúdil, že kamenná veža mohla spolu s rotundou už v 11. storočí tvorit' súčast' opevneného hradného areálu (Fiala 1976, 3-4; 1977, 13). Neskoršiu nadstavbu a oplentovanie veže tehlovým murivom s vnútorným schodiskom a hrotitými portálmi zaradil jednotne s Menclovou do 60. rokov 13. storočia a v takomto časovom určení vývoja stavby zotrval aj v neskorších publikáciách (Brunovský a kol. 1991, 27-30; Fiala 1997, 10). Rovnaké časové zaradenie výstavby veže prijala aj T. Nešporová, ktorá sa dlhodobo venovala archeologickému výskumu hradu $(1997,8)$. Avšak archeologické vrstvy, ktoré by umožnili vežu priamo datovat' a posúdit' vzájomný vzt’ah oboch stavieb, sa nezachovali (Slivka 1990, 89). Preto aj niektorí bádatelia vnímali takéto datovanie ako sporné (Feld 2015, 697) a priklonili sa skôr k mladšiemu zaradeniu výstavby veže do 12. storočia (Štefanovičová 1995, 11-12; Ruttkay 1999, 20; Slivka 2002, 17).

\section{Ciele a metódy dendrochronologického výskumu}

Terénna čast’ dendrochronologického výskumu sa zamerala na preverenie stavebnej stratigrafie a odber vzoriek zvyškov stavebných driev, zachovaných v hmote staršieho kamenného muriva na 3. nadzemnom podlaží veže. Toto podlažie patrilo podla výsledkov výskumu A. Fialu k pôvodnej súčasti najstaršej kamennej veže a na základe zvyškov kozubu malo obytnú funkciu 


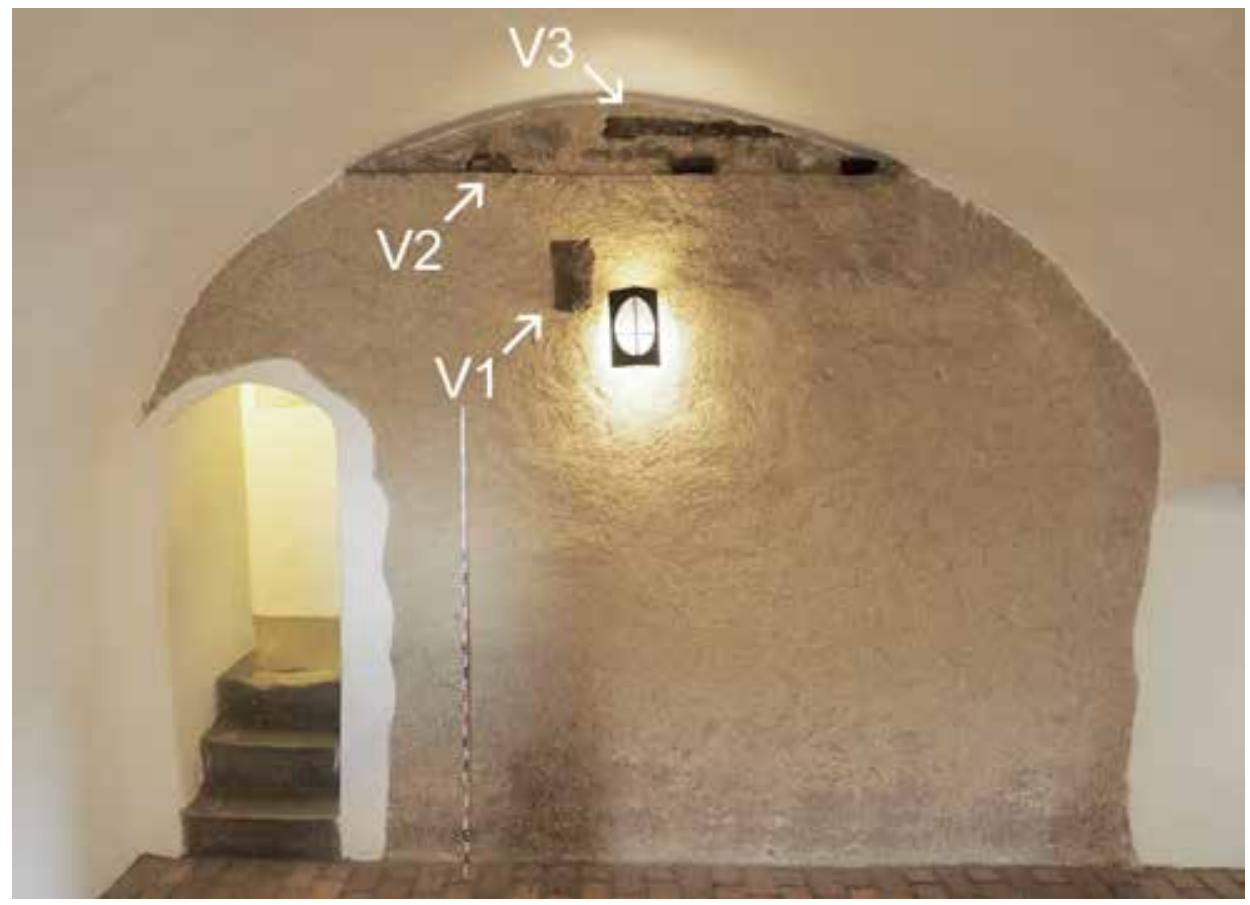

Obr. 4. Trenčiansky hrad. Severná stena 3. NP veže s vyznačením vzoriek stavebných driev. Foto M. Bóna. Abb. 4. Burg Trenčín. Nordwand 3. OG des Turms mit Kennzeichnung der Bauholzproben. Foto M. Bóna.

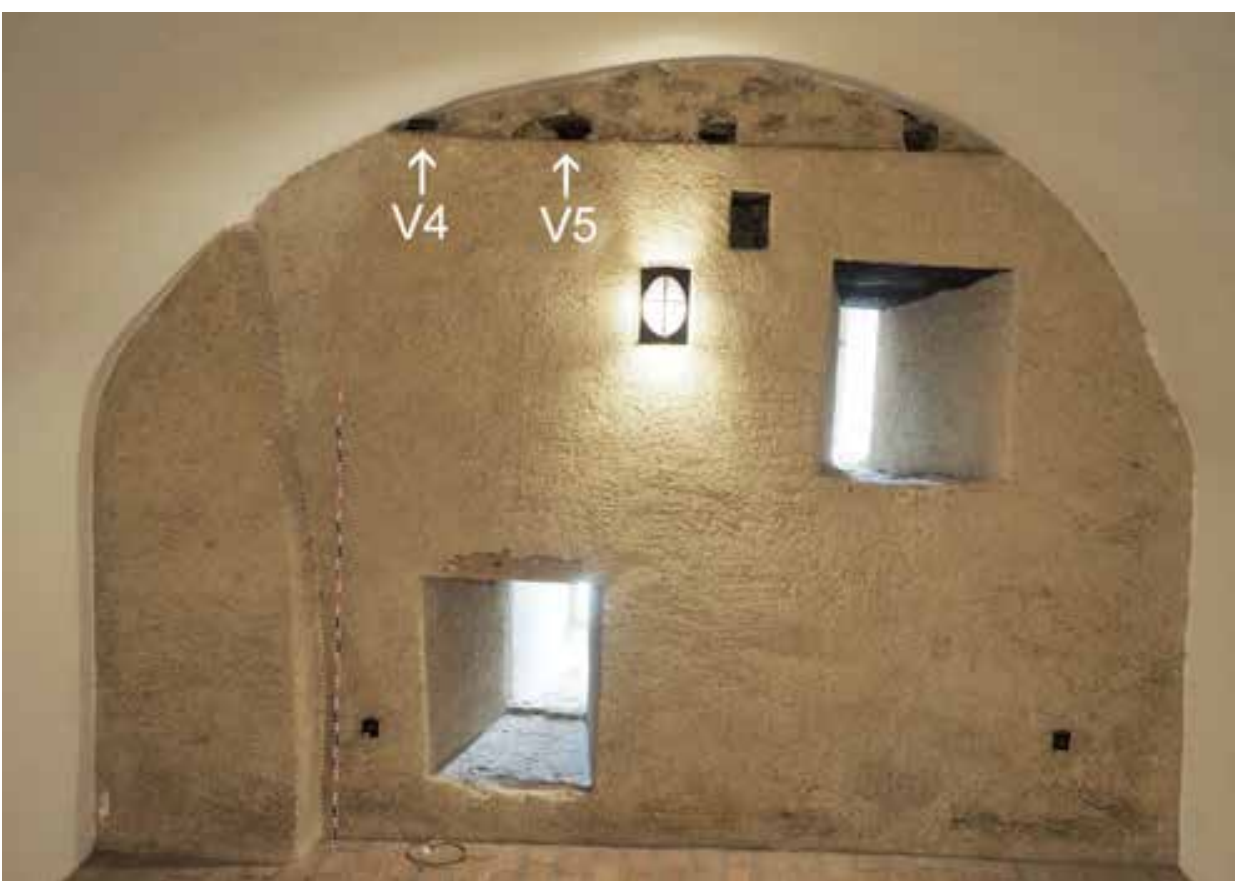

Obr. 5. Trenčiansky hrad. Južná stena 3. NP veže s vyznačením vzoriek stavebných driev. Foto M. Bóna. Abb. 5. Burg Trenčín. Südwand 3. OG des Turms mit Kennzeichnung der Bauholzproben. Foto M. Bóna. 
(Fiala 1976, 3; 1977, 13). Napriek tomu, že počas pamiatkovej obnovy v 70. rokoch 20. storočia došlo k výmene historických prekladov primárnych štrbinových otvorov v južnej stene, boli ponechané a odprezentované zvyšky stredového stropného prievlaku na severnej stene, ako aj zvyšky konzolových trámov zaniknutej ochodze v prezentovaných lôžkach oboch stien (obr. 4 a 5). Ďalšie zvyšky lôžok ochodze na východnej a západnej stene prekrýva konštrukcia mladšej valenej klenby.

Overenie primárnosti stredového prievlaku a konzolových trámov vo vzt’ahu ku kamennému murivu veže nebolo v roku 2010 ani 2018 vzhl'adom na plošne nanesenú rekonštruovanú omietku možné. Avšak podl'a výsledkov výskumu A. Fialu stropný prievlak i zvyšky ôsmich drevených konzol patrili k pôvodným detailom najstaršej kamennej vežovej stavby (Fiala 1976, 3).

Vcelku je nateraz v kamennom murive veže na 3. nadzemnom podlaží identifikovaných pät' dubových stavebných prvkov. V severnej stene je to okrem stropného prievlaku (vzorka 1) konzolový trám (vzorka 2) a pozdížny trám (vzorka 3), v južnej stene zvyšky dvoch konzolových trámov ochodze (vzorky 4 a 5). Masívny stredový prievlak obdížnikového prierezu $29 \times$ $16,5 \mathrm{~cm}$ bol situovaný $25 \mathrm{~cm}$ pod vodorovným ústupkom severnej steny, v mieste rozhrania jej 3. a 4. podlažia. Tesne nad ústupkom sa nachádzajú lôžka troch konzolových trámov šírky 15$20 \mathrm{~cm}$ a výšky $8-10 \mathrm{~cm}$, vo vzájomnom rozostupe 56 a $69 \mathrm{~cm}$, ktoré prechádzajú naprieč celým múrom 4. podlažia hrúbky $100 \mathrm{~cm}$. Na opačnej južnej stene sa tesne nad ústupkom steny nachádzajú štyri pôvodné lôžka konzolových trámov šírky $14-15 \mathrm{~cm}$, výšky $10-15 \mathrm{~cm}$, vo vzájomnom rozostupe 47, 47 a $70 \mathrm{~cm}$ (obr. 4 a 5).

Spôsob odberu vzoriek bol určený stavom zachovania trámov a ich prístupnostou v murive. Odber sa uskutočnil vrtákmi s motorovým pohonom, ručnou a elektrickou pílou a niektoré vzorky boli nasnímané aj fotograficky. Dreviny boli identifikované podl'a Schweingrubera (1990). Na jednotlivých vzorkách boli v transverzálnej rovine preparované 1-3 meracie dráhy, množstvo a priebeh ktorých záviseli od stavu zachovania vzorkovaného prvku, spôsobu odberu a pravidelnosti rastu letokruhov. Śírka letokruhov na invazívne odobratých vzorkách sa merala na meracej konzole TimeTable s presnost'ou $0,01 \mathrm{~mm}$, na fotograficky nasnímaných vzorkách $\mathrm{v}$ prostredí osm3. Všetky namerané dáta sa spracovávali v prostredí PAST4. Nedetrendrované letokruhové rady sa synchronizovali s referenčnými chronológiami a výsledok synchronizácie sa hodnotil vizuálne a štatisticky $\left(\mathrm{T}_{\mathrm{BP}}, \mathrm{T}_{\mathrm{HO}}\right.$, Gleichläufigkeit). Ako referenčné chronológie sa použili západoslovenské lokálne dubové chronológie pokrývajúce 10.-12. storočie (Považský hrad, Trnava HVIE_2), chronológia pre duby zo Slovenskej republiky SKGES13 (pre paleoklimatologický význam pozri Prokop a kol. 2016), česká dubová chronológia czges2004 a juhonemecký dubový štandard SDGES. ${ }^{3}$ Počet chýbajúcich ročných kruhov belového dreva sa dopočítal podl'a K.-U. Heussnera (1999). Z celkového počtu piatich vzoriek sa podarilo datovat' štyri (Billambozova trieda dendrochronologického datovania A; Billamboz 2005).

\section{Výsledky a vyhodnotenie dendrochronologického výskumu}

Stav zachovania drevených prvkov bol rôzny. Kým vzorky zo severnej steny,t. j. stropný prievlak (vzorka 1), konzolový trám (vzorka 2) a pozdĺžny trám (vzorka 3), sú výborne zachované takmer bez poškodenia dreva, dva dubové konzolové trámy v južnej stene (vzorky 4 a 5) boli vážne poškodené drevokazným hmyzom a zachovali sa fragmentárne.

Vzhl’adom na stavebno-konštrukčný súvis vzoriek $1,2,4$ a 5 sa najskôr $\mathrm{z}$ vizuálne a štatisticky dobre synchronizovaných vzoriek 1 a 2 (prekrytie 82 rokov; $\mathrm{TBP}=7,65$; $\mathrm{THO}=6,24$; G1. = $62,2 \%)$ vytvorila stredná krivka (TNH_MV_1,2), ktorá sa replikovane datovala na troch štandardných chronológiách (tab. 1, obr. 6). Na túto krivku vel'mi dobre vizuálne a štatisticky reaguje krátka (44 ročných kruhov) vzorka 5 (prekrytie 44 rokov; TBP = 5,67; THO =6,67; Gl. =90,9\%). Stredná krivka zo vzoriek 1, 2 a 5 (TNH_MV_1,2,5) sa tiež replikovane datuje na štandardných

3 Za poskytnutie chronológie SDGES d’akujeme K.-U. Heussnerovi (Berlín), za poskytnutie chronológie czges2004 d’akujeme M. Rybníčkovi (Brno). 


\begin{tabular}{|l|l|l|l|l|l|}
\hline Referenčná chronológia & Považský hrad & Trnava HVIE_2 & SKGES13 & czges2004 & SDGES \\
\hline $\begin{array}{l}\text { Č́slo vzorky a počet mera- } \\
\text { tel'ných ročných kruhov }\end{array}$ & & & & & \\
\hline TNH_MV_1,2; 98 & $\begin{array}{l}1238 ; 82 ; 3,76 ; \\
3,43 ; 67,1\end{array}$ & $1238 ; \mathrm{T}<1,3$ & $\begin{array}{l}1238 ; 98 ; 4,87 ; \\
3,98 ; 63,8\end{array}$ & $\begin{array}{l}1238 ; 98 ; 5,42 ; \\
5,90 ; 68,4\end{array}$ & $\begin{array}{l}1238 ; 98 ; 4,90 ; \\
4,54 ; 59,2\end{array}$ \\
\hline TNH_MV_1,2,5; 98 & $\begin{array}{l}1238 ; 82 ; 4,07 ; \\
3,82 ; 65,9\end{array}$ & $1238 ; \mathrm{T}<1,5$ & $\begin{array}{l}1238 ; 98 ; 4,52 ; \\
3,74 ; 62,8\end{array}$ & $\begin{array}{l}1238 ; 98 ; 4,86 ; \\
5,27 ; 67,3\end{array}$ & $\begin{array}{l}1238 ; 98 ; 4,32 ; \\
3,94 ; 58,2\end{array}$ \\
\hline Vzorka 3; 253 & $\begin{array}{l}1205 ; 245 ; 7,68 ; \\
8,44 ; 67,8\end{array}$ & $\begin{array}{l}1205 ; 245 ; 7,05 ; \\
7,62 ; 67,6\end{array}$ & $\begin{array}{l}1205 ; 239 ; 3,41 ; \\
4,37 ; 63,6\end{array}$ & $\begin{array}{l}1205 ; 253 ; 7,91 ; \\
8,56 ; 63,2\end{array}$ & $\begin{array}{l}1205 ; 253 ; \\
4,94 ; 4,79 ; 59,7\end{array}$ \\
\hline
\end{tabular}

Tab. 1. Trenčiansky hrad, obytná veža, dubové konštrukčné prvky. Synchronizácia stredných kriviek TNH_MV_1,2, TNH_MV_1,2,5 a vzorky 3 s referenčnými chronológiami. Pri významných synchronizáciách sú v tabul'ke uvedené: dátum pre posledný meratel'ný ročný kruh, prekrytie vzorky a štandardu v rokoch, $\mathbf{T}_{\mathrm{BP}}, \mathrm{T}_{\mathrm{но}}$, Gleichläufigkeit (\%).

Tab. 1. Burg Trenčín, Wohnturm, Eichenkonstruktionselemente. Synchronisierung der Mittelkurven TNH_MV_1,2, TNH_MV_1,2,5 und Probe 3 mit Referenzchronologien. Bei wichtigen Synchronisierungen werden folgende Añgaben in der Tabelle aufgeführt: Datum für den letzten messbaren Jahresring, Überlagerung der Probe und des Standards in Jahren, $\mathbf{T}_{\mathrm{вP}}, \mathbf{T}_{\text {но }}$, Gleichläufigkeit (\%).

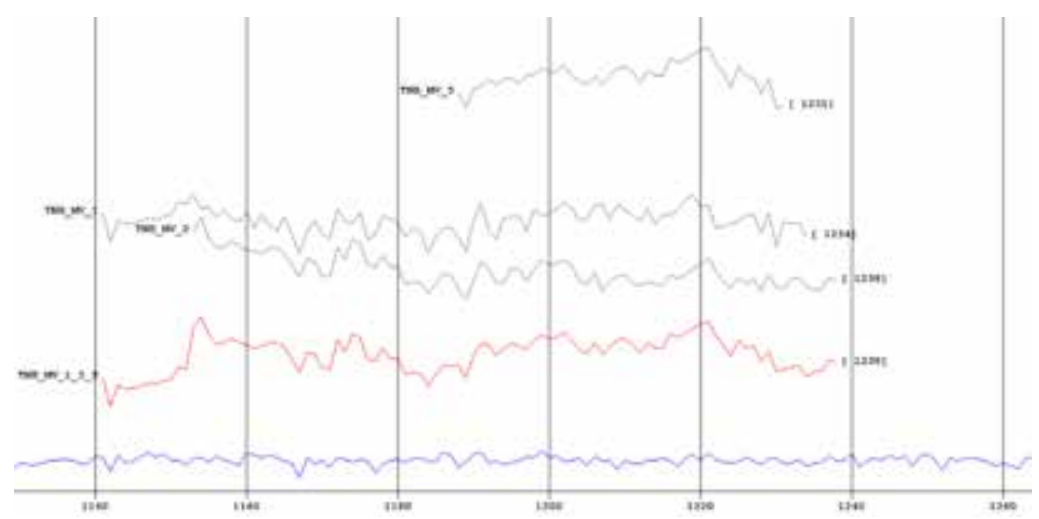

Obr. 6. Trenčiansky hrad. Synchronizácia a datovanie vzoriek $1,2,5$ z 3 . nadzemného podlažia veže so štandardnou chronológiou czges2004 (dolná krivka). Graf P. Barta.

Abb. 6. Burg Trenčín. Synchronisierung und Datierung der Proben 1, 2, 5 aus dem 3. Obergeschoss des Turms mit standardisierter Chronologie czges2004 (untere Kurve). Diagramm P. Barta.

chronológiách a jej posledný meratel’ný ročný kruh patrí do roku 1238 (tab. 1, obr. 6). Krátka vzorka 4 zostáva v tomto súbore stavebno-konštrukčne súvisiacich vzoriek nedatovaná (tab. 2).

Posledná analyzovaná vzorka 3 reprezentuje pozdížny dubový trám. Jeho stavebno-konštrukčnú funkciu a súvis s ostatnými skúmanými drevenými prvkami nie je možné vzhl’adom na muzeálno-prezentačnú úpravu interiéru veže v súčasnosti posúdit'. Vzorka 3 vel'mi dobre reaguje $(\mathrm{T}>7)$ na referenčné chronológie a jej posledný ročný kruh sa datuje do roku 1205 (tab. 1). Synchronizácia vzorky 3 so strednou krivkou vzoriek 1,2, 5 je však vizuálne nevýrazná a štatisticky slabá (1205: prekrytie 65 rokov; $\mathrm{T}_{\mathrm{BP}}=2,43 ; \mathrm{T}_{\mathrm{HO}}=3,76 ; \mathrm{Gl} .=70,00 \%$ ).

Z nameraných dát (tab. 2) a z konštrukčno-stavebných súvislostí medzi vzorkovanými prvkami je možné usudzovat', že analyzované drevá môžu reprezentovat' dve t'ažobné, a teda i stavebné aktivity. Ak predpokladáme, že vzorky 1, 2 a 5 v primárnej polohe (Fiala 1976, 3) predstavujú jeden výrub, jeho najskoršie možné (terminus a quo / terminus post quem) datovanie reprezentuje interval 1249-1269. V tomto alebo po tomto intervale (NB: vo vzorkách chýba bel'ové drevo) sa teda datuje výstavba kamenného muriva veže v 3. nadzemnom podlaží.

Vzorka 3, na ktorej sa zachovalo pät' meratel'ných ročných kruhov bel'ového dreva, reprezentuje výrub, ktorý sa odohral v intervale 1210-1230. Stavebno-konštrukčné súvislosti pozdížneho trámu, z ktorého bola táto vzorka odobratá, zostávajú zatial' nevyjasnené. 


\begin{tabular}{|l|l|l|l|l|l|l|}
\hline $\begin{array}{l}\text { Číslo } \\
\text { vzorky }\end{array}$ & $\begin{array}{l}\text { Konštrukčný } \\
\text { prvok }\end{array}$ & $\begin{array}{l}\text { Laboratórne } \\
\text { označenie } \\
\text { vzorky }\end{array}$ & $\begin{array}{l}\text { Počet meratelných } \\
\text { ročných kruhov } \\
\text { (jadrové/belové) }\end{array}$ & $\begin{array}{l}\text { Datovanie posled- } \\
\text { ného meratelného } \\
\text { ročného kruhu }\end{array}$ & $\begin{array}{l}\text { Datovanie posled- } \\
\text { ného zachovaného } \\
\text { ročného kruhu }\end{array}$ & $\begin{array}{l}\text { Datovanie } \\
\text { výrubu }\end{array}$ \\
\hline 1 & $\begin{array}{l}\text { stredový } \\
\text { stropný } \\
\text { trám }\end{array}$ & TNH_MV_1 & $94 / 0$ & 1234 & 1235 & $\begin{array}{l}\mathrm{TaQ} / \mathrm{TPQ} \\
1245-1265\end{array}$ \\
\hline 2 & $\begin{array}{l}\text { konzolový } \\
\text { trám }\end{array}$ & TNH_MV_2 & $98 / 0$ & 1238 & 1239 & $\begin{array}{l}\mathrm{TaQ} / \mathrm{TPQ} \\
1249-1269\end{array}$ \\
\hline 3 & $\begin{array}{l}\text { pozdížny } \\
\text { trám }\end{array}$ & TNH_MV_3 & $248 / 5$ & 1205 & 1206 & $\begin{array}{l}\text { TaQ } \\
1210-1230\end{array}$ \\
\hline 4 & $\begin{array}{l}\text { konzolový } \\
\text { trám }\end{array}$ & TNH_MV_4 & $26 / 0$ & nedatované & - & - \\
\hline 5 & $\begin{array}{l}\text { konzolový } \\
\text { trám }\end{array}$ & TNH_MV_5 & $44 / 0$ & 1231 & 1232 & $\begin{array}{l}\text { TaQ/TPQ } \\
1242-1262\end{array}$ \\
\hline
\end{tabular}

Tab. 2. Trenčiansky hrad, obytná veža. Datovanie výrubu analyzovaných konštrukěných prvkov vyrobených z dubového dreva.

Tab. 2. Burg Trenčín, Wohnturm. Datierung des Fälldatums der analysierten Konstruktionselemente aus Eichenholz.

\section{Záver}

Na základe výsledkov dendrochronologického výskumu a poznatkov o súvise drevených a kamenných konštrukcií vežového objektu, je možné výstavbu najstaršieho kamenného jadra obytnej veže Trenčianskeho hradu očakávat' po polovici 13. storočia, a to v intervale medzi rokmi 1249-1269, alebo neskôr (vzorky 1, 2, 5). Napriek tomu, že zachované vzorky sa nachádzajú len na 3. nadzemnom podlaží, možno toto podlažie vzhl'adom na pôvodnú štvorpodlažnost' veže i vzhl'adom na výsledky výskumu A. Fialu pokladat' za primárnu súčast' stavby a neuvažovat' tak o možnosti, že by išlo o mladšiu nadstavbu.

Vzorka 3, ktorá reprezentuje t’ažbu stavebného dreva v intervale rokov 1210-1230, ako jediná dokazuje aj staršiu, zatial' bližšie nelokalizovatel'nú stavebnú aktivitu na hrade. Súvis tejto vzorky (pozdížneho trámu) s ostatnými skúmanými prvkami (vzorky 1,2,5) nie je zrejmý a jej stavebno-konštrukčnú funkciu nie je možné skúmat' z dôvodu muzeálno-prezentačnej úpravy interiéru veže a čiastočného prekrytia prvku valenou klenbou. Domnievame sa preto, že môže íst' o druhotne použitý prvok z bližšie neznámej časti hradu, zaniknutej alebo prestavovanej v období výstavby veže.

Uvedené časové zaradenie vzniku veže do obdobia po polovici 13. storočia je podl'a najnovších zistení podstatne mladšie, než ako sa doteraz predpokladalo. Na druhej strane, s tak pokrokovým stvárnením architektonických prvkov, ako sú opracované kamenné ostenia portálov, okienok i štvrt'kruhové kamenné konzoly kozubu, sa na profánnych stavbách komitátnych hradov Uhorska stretávame v 12. storočí len vel'mi zriedkavo a je charakteristické predovšetkým pre hrady 13. storočia. Aktualizované časové zaradenie výstavby obytnej veže zároveň korešponduje aj s iniciatívou krála Belu IV., zameranou na obnovu a obranné zdokonalovanie komitátnych hradov v procese konsolidácie a obnovy spustošenej krajiny po mongolskom vpáde $1241-1242$.

V prípade komitátneho Trenčianskeho hradu zatial' nepoznáme podobu najstarších profánnych stavieb z 11. až 12. storočia a takisto ani zástavbu vel'komoravského hradiska, vybudovaného na mieste staršieho opevnenia z doby bronzovej (Nešporová 1997, 7). Podl'a doterajších nálezov sa predpokladá, že dnešný dolný hrad mohol tvorit' hospodárske zázemie akropole vel'komoravského hradiska, situovanej na mieste dnešného horného hradu. Samotné valové včasnostredoveké opevnenie sa neidentifikovalo a iba jeho južný priebeh sa predpokladá v mieste pravekého valu zo strany Breziny, ktorý bol výskumom funkčne doložený aj pre 12 . až 13. storočie (Nešporová 1997, 9). Najstaršia murovaná sakrálna stavba akropoly - tetrakonchálna rotunda bola podl’a nálezov z prilahlého cintorína zaradená najneskôr do 11. storočia (Nešporová 1974, 142-143). A aj ked' sa pripustili predpoklady jej skoršieho datovania do 10. alebo 9. storočia 


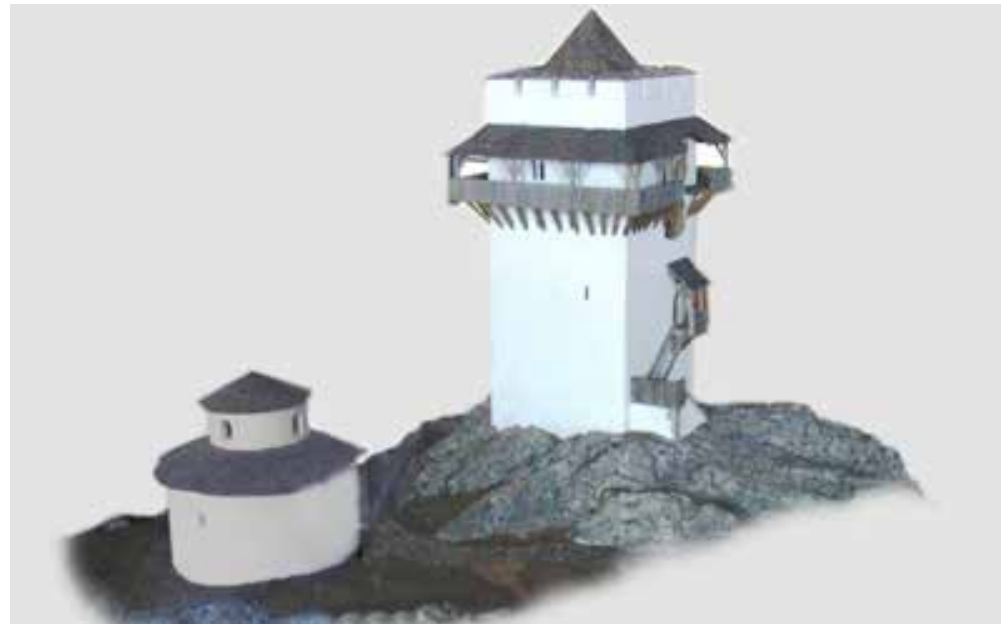

Obr. 7. Trenčiansky hrad. Model románskej podoby veže s rotundou od A. Fialu. Foto M. Bóna. Abb. 7. Burg Trenčín. Modell der romanischen Ansicht des Turms mit Rotunde von A. Fiala. Foto M. Bóna.

(Nešporová 1997, 8), väčšina odborníkov sa priklonila k jej zaradeniu do 11. storočia, a to aj s prihliadnutím na jej postupný vývoj (posledný prehlad Pomfyová 2015, 152-154).

Murovaná profánna zástavba vrcholnostredovekého hradu je podl'a doterajších zistení známa až od 13. storočia. Okrem opísanej obytnej veže v najvyššej polohe akropoly bola tvorená obvodovým murovaným opevnením. Opevnenie malo okolo veže s rotundou vymedzovat' nepravidelný lichobežníkový areál $40 \times 42 \mathrm{~m}$, avšak ucelenejšie sa doložilo len na západnej a severnej strane (Menclová 1956, 14, 161; Fiala 1979, 28-30, 49-50; Brunovský a kol. 1991, 30). Posledné výskumné zistenia ukázali, že východný úsek obvodovej hradby pokračoval viac na juh, až k miestu dnešnej 3. hradnej brány, a teda opevnená akropola mala podl'a všetkého pozdížny pôdorys a veža bola situovaná v excentrickej severnej polohe (Bóna a kol. 2019, 34).

Obytná veža sa svojimi pôdorysnými rozmermi a dispozíciou nevymyká zo súboru d’alších známych obytných veží slovenských hradov z druhej polovice 13. až 14. storočia. Najsubtílnejšie hranolové veže sa zachovali na hradoch Lietava $(5,6 \times 6 \mathrm{~m})$, Lednica $(5,5 \times 6,5 \mathrm{~m})$, Vršatec $(6 \times$ $6 \mathrm{~m})$ a L’upča $(6,5 \times 6,8 \mathrm{~m})$, pričom pôdorysnými rozmermi sa trenčianskej veži najviac blížia veže hradov Dobrá Voda $(7,7 \times 7,7 \mathrm{~m})$ a Strečno $(8 \times 8 \mathrm{~m})$. Z územia niekdajšieho Uhorska sa rozmerom trenčianskej veži najviac približujú obytné veže menších hradov Bibervár $(6,8 \times 7,8 \mathrm{~m}$; Miklós 1983, 13) a Várfő (7 × 7,5 m; Miklós 1998, 129) v dnešnom Mad’arsku, avšak u väčšiny skúmaných hradov dosahujú obytné hranolové veže 13. až 14. storočia väčšie rozmery (bližšie Feld 2000).

K upresneniu datovania mladšej ranogotickej prestavby trenčianskej veže sa nepodarilo identifikovat' zatial' žiadne prvky vhodné na dendrochronologickú analýzu. Doterajšie datovanie opláštenia a nadstavby tehlovým murivom do 60. rokov 13. storočia (Menclová 1956, 12-13; Brunovský a kol. 1991, 29-30) sa vzhl'adom na vznik staršieho jadra veže javí skoré. Avšak nemožno na úrovni dnešného poznania tiež vylúčit', že k tomu došlo v nasledujúcich desat'ročiach 13. storočia. Podobné a časovo blízke opláštenie staršej románskej veže preukázal aj archeologický výskum obytnej veže Pustého hradu vo Zvolene (Beljak-Beljak Pažinová 2018, 207; Beljak-Beljak Pažinová-Šimkovic 2018, 25).

S najmladšími ranogotickými úpravami obytnej veže z obdobia držby hradu Matúšom Čákom Trenčianskym (1296-1311) sa doteraz spájalo zaklenutie hlavnej obytnej miestnosti na 5. nadzemnom podlaží a výstavba niektorých objektov po obvode severného predhradia (Brunovský 


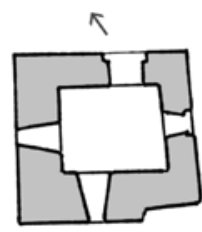

LIETAVA

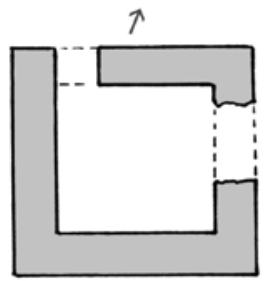

TRENČÍN

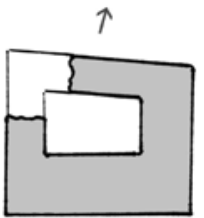

LEDNICA

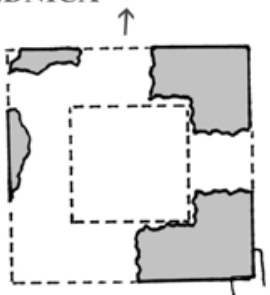

DOBRÁ VODA

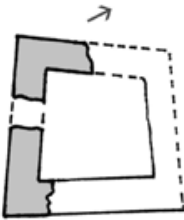

VRŠATEC

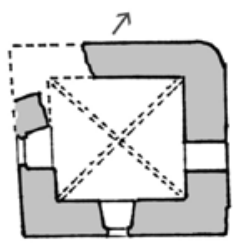

LUPČA

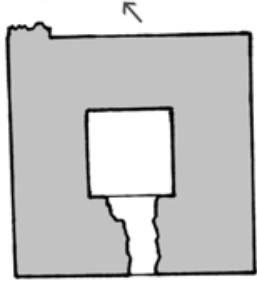

STREČNO
$03 \mathrm{~m}$

Obr. 8. Príklady pôdorysov hranolových hradných veží z 13. až 14. storočia na území Slovenska. Kresba M. Bóna. Abb. 8. Beispiele für die Grundrisse von Rechtecktürmen aus dem 13. bis 14. Jahrhundert auf dem Gebiet der Slowakei. Zeichnung M. Bóna.

a kol. 1991, 34-36). Nedávne pamiatkové i dendrochronologické výskumy ale preukázali, že Čákova stavebná aktivita bola podstatne rozsiahlejšia a v prvom desat'ročí 14. storočia sa sústredila aj na vybudovanie murovaného opevnenia severného predhradia. $Z$ jeho konštrukcií sa dodnes ucelene zachoval juhovýchodný úsek s vrcholovým cimburím, datovaný prostredníctvom ochodzových trámov medzi roky 1298-1312 (Matejka-Bóna 2016, 29; Choma-Barta 2016, 1-3).

Na záver si dovol'ujeme dodat', že napriek posunu datovania vzniku obytnej veže Trenčianskeho hradu do doby po polovici 13. storočia, táto stavba nepochybne nad’alej patrí k najvýznamnejším reprezentantom stavieb svojho druhu na území Slovenska. A to nielen pre svoju ucelenú zachovanost', ale aj pre množstvo autentických stavebných prvkov, ktoré obohacujú poznanie architektúry našich stredovekých fortifikačných stavieb.

Príspevok je venovaný pamiatke PhDr. Tamary Nešporovej (28. 11. 1942 - 10. 10. 2006), ktorá sa ako archeologička Trenčianskeho múzea významnou mierou zaslúžila o výskum Trenčianskeho hradu.

Tento výskum bol podporený Agentúrou pre výskum a vývoj na základe zmlúv APVV-0598-10 a APVV-14-0550, spoločnostou ProMonument s.r. o., Zlaté Moravce a sponzormi Dendrochronologického laboratória Bratislava.

\section{Pramene a literatúra}

BELJAK, J.-BELJAK PAŽINOVÁ, N., 2018: Výskum a obnova Pustého hradu vo Zvolene. In: Beljak Pažinová, N.-Borzová, Z., Stredné Slovensko v stredoveku - Vývoj osídlenia regiónu pred udelením mestských privilégií mestu Zvolen, 212-235. Zvolen.

BELJAK, J.-BELJAK PAŽINOVÁ, N.-ŠIMKOVIC, M., 2018: Pustý hrad vo Zvolene a hrad Petuša vo svetle aktuálnych výskumov. Zvolen.

BILLAMBOZ, A., 2005: Classes of dating quality. In: Abstract Book of Eurodendro 2005, International Conference of Dendrochronology, 28. 9. - 2. 10. 2005, Viterbo, Italy (Sarlatto, M.-Di Filippo, A.-Piovesan, G.-Romagnoli, M., edd.), 12. Viterbo. 
BÓNA, M. a kol., 2019: Trenčín - Trenčiansky hrad. Architektonicko-historický výskum vybraných objektov v juhovýchodnej časti hradného jadra. Výskumná dokumentácia 2019, ulož. v Archíve KPÚ $\mathrm{V}$ Trenčíne.

BRUNOVSKÝ, F. a kol., 1991: Brunovský, F.-Fiala, A.-Nešporová, T.-Šišmiš, M., Trenčiansky hrad. Martin.

FELD, I., 2000: 13. századi nemesi várak toronyépületei. In: Castrum Bene Hírlevél (Terei, Gy., szerk.). Budapest.

- 2015: Királyi várak az Árpád-kori medium regni területén. In: In medio regni Hungariae: régészeti, művészettörténeti és történeti kutatások „,az ország közepén“(Benkő, E.-Orosz, K., edd.), 677-704. Budapest.

FIALA, A., 1976: Trenčín - hrad, Matúšova veža - dodatok PPÚ. Výskumná dokumentácia 1976, ulož. v Archíve KPÚ v Trenčíne.

- 1977: Obytná veža Trenčianskeho hradu, Pamiatky a príroda VII, č. 2, 13-15.

- 1979: Trenčín - Hrad NKP. Doplnkové výskumy a PPÚ v jednotlivých situáciách horného hradu a vel'kého nádvoria vypracované podl’a postupu opravných prác v r. 1978-1979. Výskumná dokumentácia 1979, ulož. v Archíve KPÚ v Trenčíne.

- 1988: Obnova Matúšovej veže Trenčianskeho hradu, Ochrana pamiatok a prírody v západoslovenskom kraji, č. 2, 73-74.

- 1997: Premeny Trenčianskeho hradu, Pamiatky a múzeá, č. 3, 10-13.

HEUSSNER, K.-U., 1999: Wieviel fehlt? - Ein Beitrag zur Genauigkeit von dendrochronologischen Datierungen. In: Den Bogen spannen... Festschrift für Bernhard Gramsch zum 65. Geburtstag. Beiträge zur Ur- und Frühgeschichte Mitteleuropas 20 (Cziesla, E.-Kersting, T.-Pratsch, S., edd.), 523-525. Weissbach.

CHOMA, M.-BARTA, P., 2016: Dendrochronologický výskum stavebných konštrukcií na Trenčianskom hrade, okr. Trenčín. Dendrochronologické laboratórium Bratislava. Výskumná dokumentácia 2016, ulož. v Archíve KPÚ v Trenčíne.

MATEJKA, M.-BÓNA, M., 2016: NKP Hrad Trenčín. Architektonicko-historický výskum PO múr hradbový IX. a batéria. Výskumná dokumentácia 2016, ulož. v Archíve KPÚ v Trenčíne.

MENCLOVÁ, D., 1956: Hrad Trenčín. Bratislava.

- 1973: Príspevok k typológii hradov, zámkov a kaštiel’ov na Slovensku. In: Pisoň, Š., Hrady, zámky a kaštiele na Slovensku, 397-445. Martin.

MIKLÓS, Zs., 1983: Ásatás Márianosztra-Biberváron, Archaeologiai Értesitő 110, č. 1, 10-23.

- 1998: Váralja-Várfö XIII. századi vára, A Wosinszky Mór Múzeum Évkönyve 20, 127-156.

NEŠPOROVÁ, T., 1974: Výsledky historicko-archeologického výskumu na Trenčianskom hrade, Vlastivedný časopis XXIII, č. 3, 142-143.

- 1997: Hrad Trenčín v archeologických prameňoch, Pamiatky a múzeá, č. 3, 6-9.

POMFYOVÁ, B. a kol., 2015: Stredoveký kostol - historické a funkčné premeny architektúry. I. zv. Bratislava.

PROKOP, O. a kol., 2016: Prokop, O.-Kolář, T.-Büntgen, U.-Kyncl, J.-Kyncl, T.-Bošel’a, M.-Choma, M.Barta, P.-Rybníček, M., On the palaeoclimatic potential of a millennium-long oak ring width chronology from Slovakia, Dendrochronologia 40, 93-101. https://doi.org/10.1016/j.dendro.2016.08.001

RUTTKAY, A., 1999: Feudálne sídla na Slovensku do polovice 13. storočia, Pamiatky a múzeá, č. 2, 19-23.

SCHWEINGRUBER, F. H., 1990: Mikroskopische Holzanatomie. Birmensdorf.

SLIVKA, M., 1990: Die Anfänge des Burgbaues in der Ostslowakei, Castrum Bene - Várak a 13. században, 1989, 86-93.

- 2002: Veže ako dominanty domínií (Symbolika a geneticko-typologický vývoj na Slovensku), Archaeologia Historica Polona 12, 9-29.

ŠTEFANOVIČOVÁ, T., 1995: K vývoju stredovekých hradov na Slovensku v 11. až 13. storočí, Zborník FF UK - Historica XLI, 7-11.

\section{Zusammenfassung}

\section{Ergebnis der dendrochronologischen Untersuchung des Wohnturms von Burg Trenčín}

Der komplett erhaltene siebenstöckige Rechteckturm bildet im zentralen Teil der oberen Burg auf dem Gipfel eines Kalksteinfelsens die Dominante. Seine detaillierte architektonisch-historische Untersuchung wurde im Jahr 1976 von A. Fiala durchgeführt. In der Masse 
des stehenden Gebäudes mit Ziegelsteinmantel identifizierte er einen älteren Steinkern, dessen Entstehung er anhand des Fundes und der archäologischen Datierung eines benachbarten Sakralbaus (Rotunde) im 11. Jahrhundert vermutete. Einige Forscher tendieren jedoch zu der Möglichkeit einer späteren Datierung des Turms in das 12. Jahrhundert (Ruttkay, Štefanovičová, Slivka).

Die dendrochronologische Untersuchung des Holzes am Turm wurde in den Jahren 2010 und 2018 mit dem Bestreben durchgeführt, den ältesten Teil des Turmes präziser zu datieren. Die Bauelemente, von denen Proben genommen wurden, sind im dritten Obergeschoss erhalten geblieben und bildeten in der Vergangenheit den mittleren Durchzugsbalken der Balkendecke sowie Balkenkonsolen des zum ältesten Steinturm gehörenden Wehrgangs. Anhand der gemessenen Daten (Tab. 2) und den konstruktionsbautechnischen Zusammenhängen zwischen den Elementen, von den die Proben genommen wurden, kann man schließen, dass das analysierte Holz zwei Holzgewinnungsaktivitäten und demnach auch zwei Bauaktivitäten repräsentiert. Die Proben 1, 2 und 5 in Primärlage (Fiala 1976, 3) stellen eine Fällung dar, aufgrund welcher man den Bau des ältesten Steinkerns des Wohnturms in der Zeit nach Mitte des 13. Jahrhunderts erwarten kann, und zwar zwischen den Jahren 1249-1269 oder später.

Probe 3, welche eine Gewinnung von Bauholz im Intervall der Jahre 1210-1230 repräsentiert, liefert als einzige auch eine ältere, bislang nicht näher lokalisierbare Bauaktivität auf der Burg. Der Zusammenhang dieser Proben mit den übrigen untersuchten Elementen (Proben 1, 2, 5) ist nicht offensichtlich, es handelt sich dabei wahrscheinlich um eine sekundäre Verwendung von Elementen eines nicht näher bekannten Teils der Burg, der untergegangen ist oder während des Baus des Turms umgebaut wurde.

Die angegebene zeitliche Einordnung der Entstehung des Turms in die Zeit nach Mitte des 13. Jahrhunderts ist wesentlich jünger als man bisher angenommen hat. Andererseits korrespondiert dies sowohl mit der Architektur und den Abmessungen weiterer bekannter Wohntürme aus dem 13.-14. Jahrhundert (die Burgen Lietava, Lednica, Vršatec, L’upča, Dobrá Voda und Strečno), als auch mit dem Bestreben von König Bela IV., Komitatsburgen während des Wiederaufbaus des nach dem Mongoleneinfall von 1241-1242 verwüsteten Königreichs wieder aufzubauen und ihre Verteidigung zu perfektionieren.

Der vorliegende Beitrag ist dem Gedenken an Frau PhDr. Tamara Nešporová (28. 11. 1942 - 10. 10. 2006) gewidmet, die sich als Archäologin des Trenčiner Museums in beträchtlichem Maße um die Erforschung der Burg Trenčin verdient gemacht hat.

Die Untersuchung wurde von der Agentur für Forschung und Entwicklung auf Grundlage der Verträge APVV-0598-10 und APVV-14-0550, von der Gesellschaft ProMonument s.r. o., von Zlaté Moravce und von den Sponsoren des Dendrochronologischen Labors Bratislava gefördert.

Mgr. Peter Barta, PhD., Katedra archeológie Filozofickej fakulty Univerzity Komenského v Bratislave, Gondova 2, 81499 Bratislava, Slovenská republika, peter.barta@uniba.sk

Ing. arch. Martin Bóna, PhD., privátny bádatel', ProMonument s. r. o., Štefánikova 14, 95301 Zlaté Moravce, Slovenská republika, bona.martin@gmail.com 
